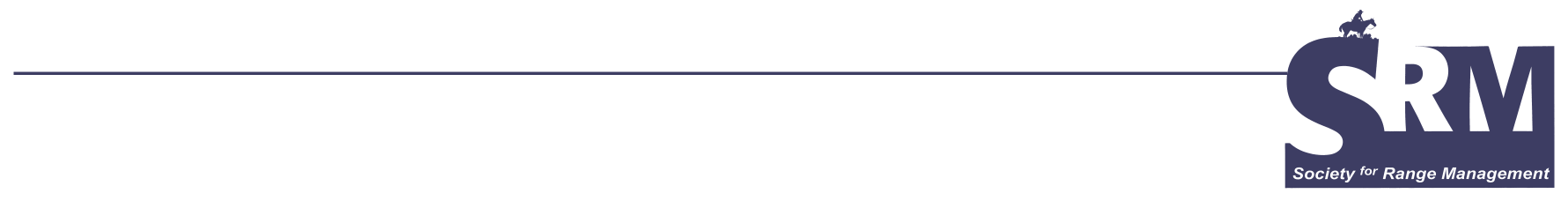

\title{
"Doing the Best We Could With What We Had": USFS Range Research in the Southwest
}

\section{By Susan Deaver Olberding, John E. Mitchell, and Margaret M. Moore}

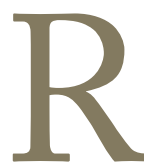

etired southwestern US Forest Service (USFS) range technician Bill Kruse spoke the above words when asked about range research work in the 1960s. His remarks indicate the scope of vital work at hand yet with scarce available resources. The USFS rangeland studies program has always eked along with few funds and scientists attempting to do many types of projects designed to sustain and improve rangelands for multiple uses. But the early scientists who worked in the Southwest reads like a "Who's Who" list. This essay covers the southwestern range studies from the early 1900s until about 1970 when rangeland research became funded under other projects like watershed studies.

\section{Before Rangeland Science Began: 1860s-1890s}

"... it looked as if a fire had gone through there-wasn't a blade of grass, wasn't an oak leaf in reach of a cow, not one ..." said USFS ranger C. A. Merker about the rangelands of Cameron and the Grand Canyon South rim in the 1920s. ${ }^{1}$ Beginning in the 1870s, thousands of cattle were moved into the Southwest to feed on the open rangelands. Sheep, of course, had already been in the Southwest for 300 years before the cattle arrived, but sheep numbers also rapidly expanded during the 1880s and 1890s, reaching their peak around $1910 .^{2}$ Those decades of heavy grazing altered and deteriorated the range. Drought, a common occurrence in the Southwest, further hindered plant recovery and resulted in heavy livestock losses. Eager settlers sought homesteads, preferably with water sources, and most did not understand the fragile ecosystems of the Southwest and their need for rest.
Vegetation in the southwestern range types was unaccustomed to grazing by large numbers of grazing animals; thus, the plants had not evolved to resist or tolerate high amounts of grazing pressure. People assumed the plant species would naturally regenerate from grazing as they had seen in other regions. However, the bunchgrasses in the higher elevations and black grama grass in the southern areas did not recover. In the Southwest, plants are so susceptible to injury that game trails and wagon ruts stay visible for years, even after the disturbance stops. Native plants have adapted to unpredictable precipitation and await their cue from the summer monsoon season to grow. But in the late 19th and early 20th centuries, hungry, grazing animals and their owners did not wait for the plant's optimal time, and plants were required to work when they should have been resting. The tremendous numbers of hooves treading on the soil promoted erosion and the formation of arroyos because there was very little vegetation to protect the soil surface.

Ranges were denuded in most places, causing statements like Merker's. Foraging animals invaded canyons and steep slopes where juniper trees thrive. Tree and shrub seeds then lodged in wool and hooves and were carried onto the open grasslands where they dropped. The seeds were stomped into the ground, which enabled them to become established. The combination of overgrazing, seed dissemination, possible climate change, and fire cessation caused the junipers to spread across the formerly open grassland. ${ }^{3,4}$ In the hot, drier areas, mesquite and other desert shrubs spread the same way, further diminishing the available grass.

By the late 1800s, the deterioration of the western ranges was obvious. Local ranchers voiced concern because their livelihoods depended on sustainable forage. Several visionary 


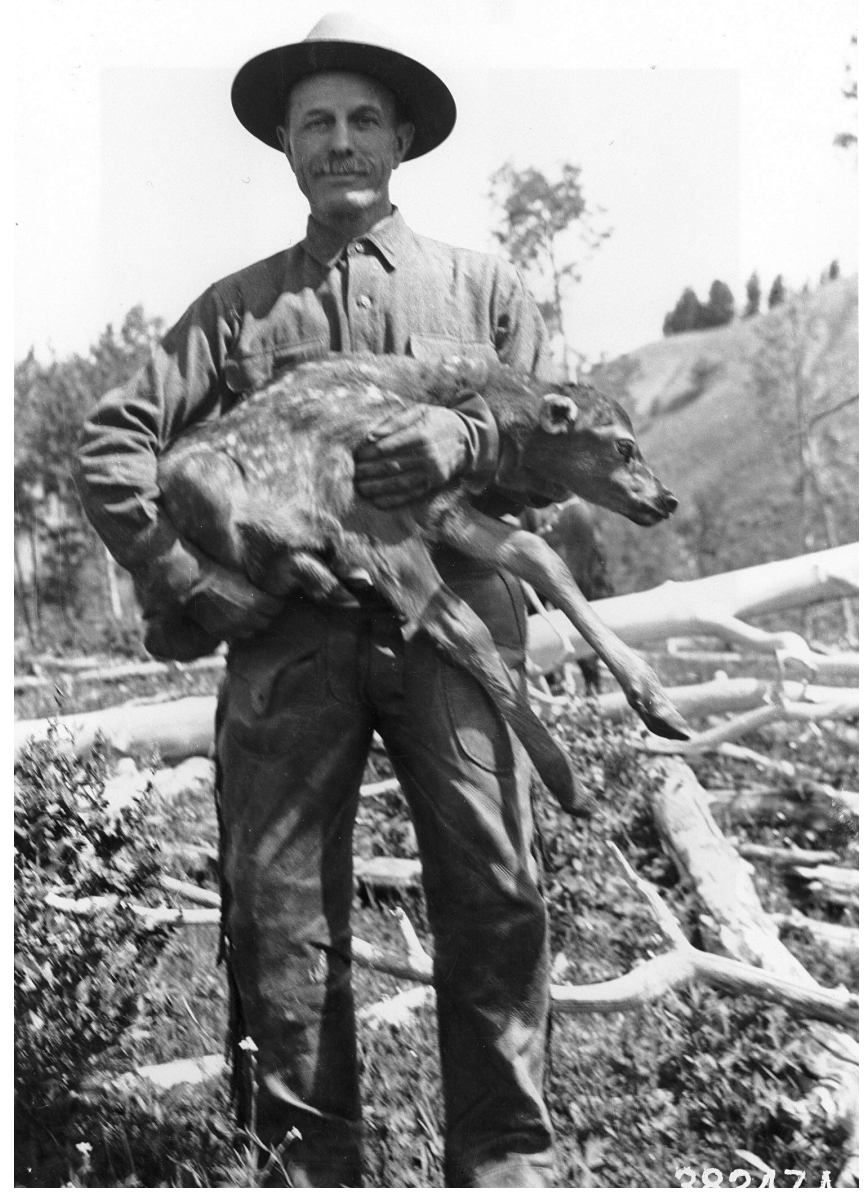

Figure 1. Associate Forester Albert F. "Bert" Potter, eastern Arizona rancher and first administrator of the Forest Service grazing program, with an elk calf in his arms. The caption reads: "This calf appears so docile, one would hardly think that he is vigorous and strong and capable of putting up a strong fight in his own defense, yet this is evidently not his custom." Photo taken on the Teton National Forest, Wyoming by Smith Riley in 1918. Photo courtesy of Forest History Society.

botanists, such as James W. Toumey, University of Arizona, ${ }^{5}$ and Elmer O. Wooton, with the New Mexico College of Agriculture (now New Mexico State University), ${ }^{6}$ warned of the impending danger of overgrazing the range grasses. Finally, Congress authorized funding for range research through federal agencies in 1895.

\section{Southwestern Rangeland Research Begins}

By 1900, federal resource protection agencies evolved, among them the precursor to the USFS. Washington bureaucrats pushed to preserve watersheds and forests but not so much the rangelands. Talk of limiting livestock on the forests to protect watersheds reached the stockmen in the Southwest, and some traveled to Washington to plead their case about needing access to free grass to earn a living but yet also supporting some regulation of the numbers of animals grazing.
Finally, Albert F. "Bert" Potter, livestock man from the Holbrook/St. John's area of Arizona, convinced two bureaucrats to see the Arizona rangeland devastation first hand (Fig. 1). The account of this trip by Division of Forestry (now USFS) Chief Gifford Pinchot and Bureau of Plant Industry (BPI) botanist Frederick V. Coville in June 1900 has been told. ${ }^{7}$ By the end of the three-week trip, the two Easterners had proved their meddle with the hardy stockmen, and respect for the Westerners was felt by the bureaucrats. As a result, Pinchot asked Potter to join the USFS and direct the establishment of a public lands grazing program.

Bert Potter moved to Washington, DC, but spent a lot of time traveling to western livestock association meetings. He addressed the 1911 National Woolgrowers Association with "the first thing was to check the damage and waste with the least possible curtailment of grazing privileges." Ranchers pushed for policies that applied to local conditions, not nationwide rules. Potter hired former stockmen to develop policy as he thought men who had "ridden the range" would be the best advisors. He needed scientific studies on the range and worked with Coville to form the USFS Office of Grazing Studies in 1910. This division was headed by James T. Jardine, a former Idaho cowboy and recent graduate of Utah Agricultural College, who was initially hired by Coville in 1907 to work on sheep grazing in Oregon's Wallowa National Forest. Jardine was appointed USFS Inspector of Grazing in 1909, Chief of Grazing Studies in 1910 (which later became the Division of Range Management Research), and he visited many western National Forests making management recommendations. Jardine authored a publication with Mark Anderson that is still considered a classic, Range Management on the National Forests. ${ }^{8}$

In 1911, Jardine hired men who were to lead newly established Regional Offices of Grazing Studies in the western Districts of the USFS. ${ }^{9}$ It was groundbreaking work with no precedence to follow. Jardine met up with these fledgling researchers during the spring of 1911 on the Coconino National Forest in northern Arizona for a five-week training session on range reconnaissance, the nation's first. The scientists inventoried conditions, mapped range types, recorded vegetation, and evaluated range conditions. ${ }^{10}$ They quickly realized they knew little of the native plants and their attributes and collected many specimens to study.

Robert R. Hill was one of the team members. He had already been involved in rangeland work for District 3 (now USFS Region 3) when he became the District's Chief of Grazing Studies. In 1910, he and G. A. Pearson, Director of the Fort Valley Experimental Forest Station (FVEFS) located on the Coconino National Forest northwest of Flagstaff, established grazing plots on the Coconino to ascertain grazing effects on tree regeneration. ${ }^{11-13}$ By 1912, Hill focused his efforts on permanent sample plots at Rees Tank, Rogers Lake, Frye Park, Black Springs, and Big Fill in northern Arizona. ${ }^{14,15}$ Hill, assisted by W.R. Chapline who later became the USFS Director of Range Management 
Research, fenced about 2 acres per sample location to exclude livestock and measured vegetation on quadrats within the exclosures. He also set up other nearby quadrats, which remained open to grazing. These plots were monitored for three decades. Hill's conclusions in 1923 were that "The come-back of overgrazed ranges is much slower than most people believed. ${ }^{114}$ Periodic remeasurement of these permanent sample plots continued until 1947,15,16 and Northern Arizona University, School of Forestry graduate student Jonathan Bakker has resurrected this work and remeasured these historical plots (Fig. 2). ${ }^{17}$

Silviculturist G. A. Pearson hated livestock grazing around his trees and initially tried to abolish grazing on the National Forests. ${ }^{18} \mathrm{He}$ set out to prove his case when he realized this would not occur. In 1910, he established two large study areas, both on the Tusayan (later the Kaibab) National Forest, one at Willaha (in the pinyon/juniper type and a sheep pasture) and the other at Wild Bill (in the pines and a cattle pasture). Various experiments, backed by extensive field records, studied injury to pine reproduction, seedling establishment, forage production, bunchgrass fire hazard, response to protection, and use standards. At the time, USFS field employees kept diaries or notebooks that provide wonderful glances into the activities of these early scientists. One unidentified diarist wrote of his charges, named "Red Eye" and "Herman," at Wild Bill on June 25, 1932: ${ }^{19}$ "I notice that these steers would be grazing contentedly and then would reach up and delibertly [sic] eat some juicy pine. They would chew this slowly with evident satisfaction."

Conclusions about the Wild Bill and Willaha studies indicated that pine shoots were not browsed after July 15 th, the start of the summer monsoon season, so Pearson suggested withholding grazing until then. He also recommended a limit of a one-night, bed ground to reduce needle browsing; more watering tanks to lessen the impact on trees surrounding the water holes; and providing salt for the livestock. He said inferior grasses supplanted the best grasses because stock ate the best grasses down to the ground so they could not reseed. His summaries showed that influential factors affecting timber reproduction include the amount of "tasty" forage available during the summer months and the length of time livestock are permitted to graze. ${ }^{20}$ Pearson's stance against livestock did not endear him to the range scientists, creating a controversy that raged for three decades before his retirement.

Charles K. Cooperrider was among those scientists with whom Pearson disagreed. "Coop" had accepted a USFS position on the Santa Fe National Forest in 1915, hoping to improve his fragile health in the arid Southwest. He quickly realized the dangers of erosion from too many cattle. He would later be assigned to District 3 headquarters as a range scientist, and eventually was Director, but he is remembered today for his watershed studies. "Coop" worked on the Willaha and Wild Bill study areas, coauthored the 1924 Coconino Range Appraisal Survey with R. W. Hussey, led range reconnaissance, surveyed conditions on private range-
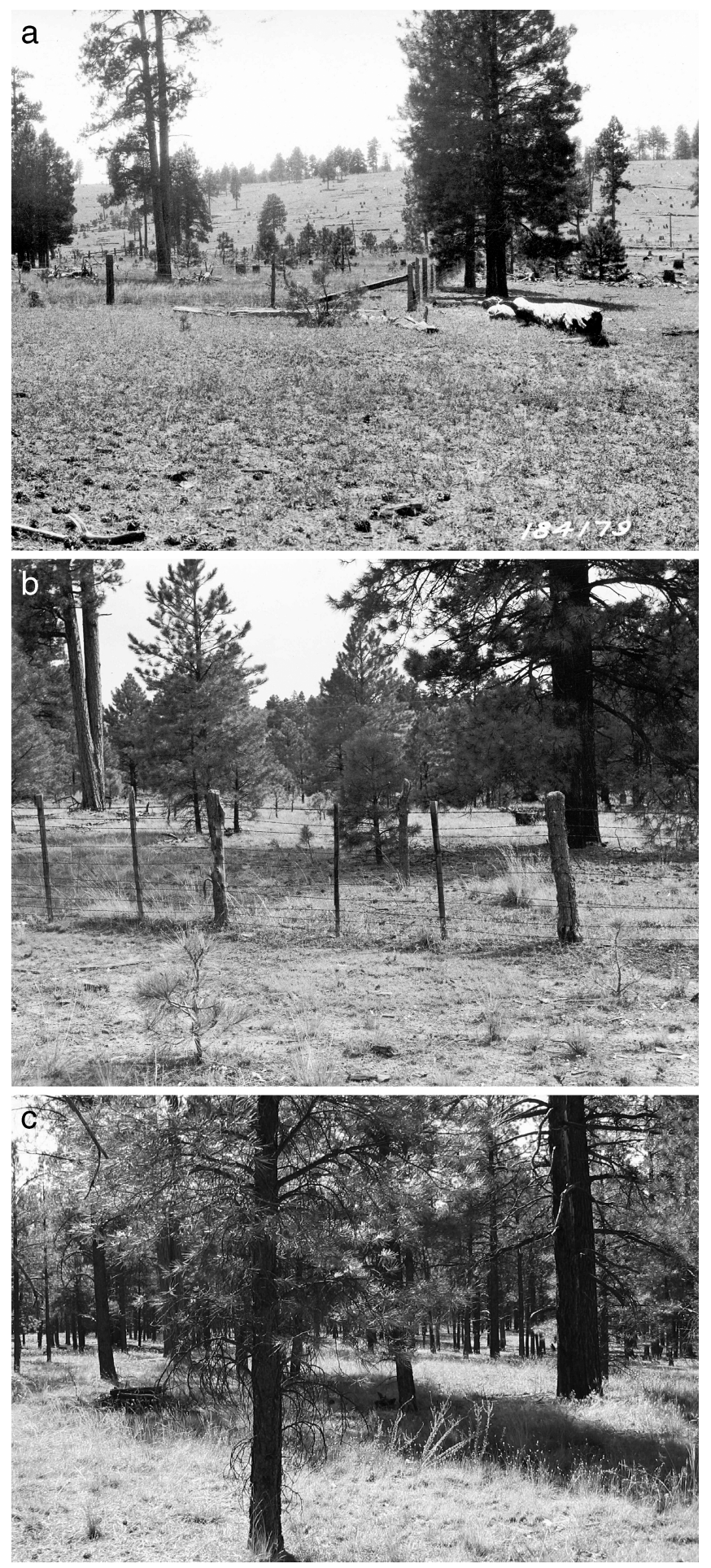

Figure 2. Repeat photographs of Black Springs, one of the original Hill plots established in 1912. The 1923 photo (top) was taken by M. W. Talbot (FS 184179), the 1947 photo (middle) by K. W. Parker (K1140A), and the 2003 photo (bottom) by J. D. Bakker. The 1923 photo was taken from a slightly different angle than the other photos, although some of the same trees are evident in all photos, especially the large tree to the right and the large forked tree to the left (although this tree is blocked by younger trees in the 2003 photo). The fence was moved $10 \mathrm{~m}$ to the right in 1931, and deteriorated between the 1947 and 2003 photos. Historical photos courtesy of USFS Rocky Mountain Research Station, FVEFS Archives, Flagstaff, AZ. 
a

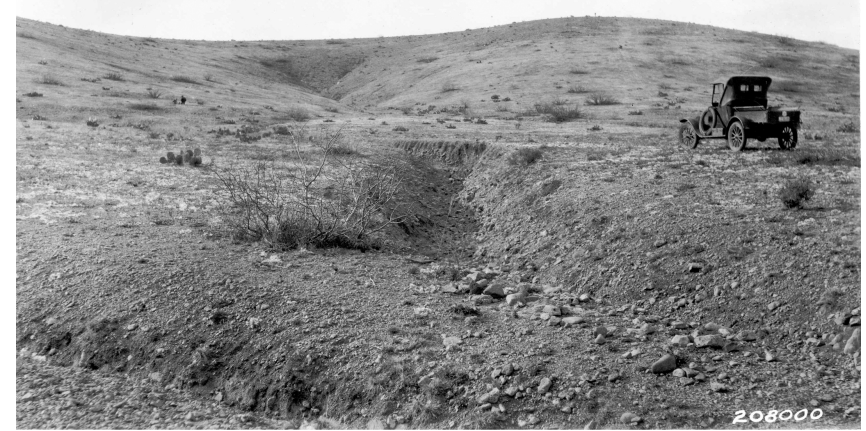

b

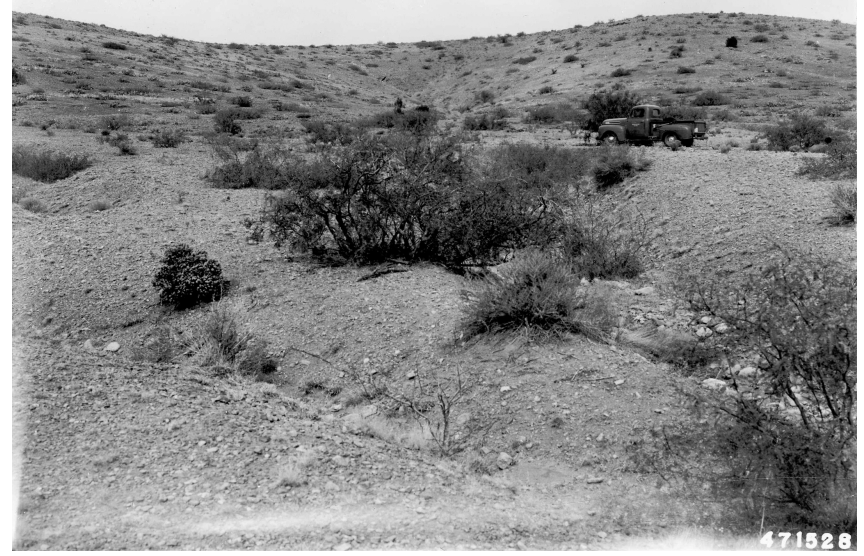

Figure 3. Repeat photos from a private range near the Gila National Forest in New Mexico. The top photo, taken by C. K. Cooperrider in April 1926, shows the cover and erosion. The follow-up photo, taken in October 1952 by J. F. Arnold, indicates the establishment of vegetation in the gullies and a marked increase in shrubby species. Historical photos courtesy of USDAFS Rocky Mountain Research Station, FVEFS Archives, Flagstaff, AZ.

land near the Gila National Forest (Fig. 3), directed the 1931 study of the Rio Grande watershed, established the Parker Creek (later Sierra Ancha) Experimental Watershed in central Arizona, among other projects. When appropriations allowed the USFS to expand its range studies in the late 1920s, "Coop" was assigned to FVEFS as Director of Range Studies where he and Pearson continued their dispute. During World War II, "Coop" went to Mexico with the Guayule rubber project where his poor health worsened, and he died in 1944 at 55 years of age.

Research results emanating from southwestern scientists caused local stockmen, especially sheep raisers, to protest evidence that overgrazing impaired range health. Efforts to discredit the scientists and their work and suppress the findings led to political pressure to close FVEFS. During a joint meeting of the Arizona Woolgrowers Association (of which Bert Potter was once an officer) and the Arizona Cattle Growers Association in July 1920, a resolution passed by the conference members said the Fort Valley Experiment Station was considered worthless because: “...the work has been an entire failure and a useless expense to the amount of approximately $\$ 20,000$ per annum...be abandoned and that the lands occupied by it be restored to entry..." reported the Flagstaff Coconino Sun newspaper of July 9, 1920. A letter from Secretary of Agriculture Edwin T. Meredith to Charles Mullen, president of the Arizona Cattle Growers Association, asked for specifics as to where FVEFS had failed. The apologetic response blamed "some sheepmen" for the resolution that weary cattlemen approved without realizing what they were doing. FVEFS remained open. ${ }^{19}$

Scientist M. W. Talbot, in charge of District 3's Office of Grazing Studies by 1920, was instrumental in the development of rangeland and watershed management as southwestern range work continued to focus on plant identification, evaluations of grazing damage, use studies, and revegetation. ${ }^{21}$ In 1937, Talbot revised the 1919 publication targeted to USFS District 3 forest officers titled How to Judge Southwestern Range Conditions under the new title Indicators of Southwestern Range Conditions. It was published by USDA as Farmers' Bulletin No. 1782. This easy-to-read guide aided both USFS rangers and stockmen.

Rangeland projects in the early years evaluated the seeding of exotics and native species. A 1913 study looked at native plants to see if they would survive and produce seed under cultivation. Research was conducted using other rangeland grazing animals such as goats, horses, and wildlife. For example, Chapline led a 1917 study of goats in New Mexico in response to high demand for mohair wool..$^{22} \mathrm{He}$ knew the Forest officers wanted him to pull the goats, but he found that controlled grazing was acceptable. Some discussions with goat owners about grazing habits were necessary, however.

In the meantime, another controversial story was unfolding on the Kaibab Plateau in northern Arizona. President Teddy Roosevelt would designate the Plateau as a National Game Preserve in 1906, with focus on the local deer herds. Establishment of the game preserve meant no deer hunting and aggressive predator control, which contributed to an overabundant deer population. Continued grazing (possible overgrazing) by livestock and deer, plus periodic drought, led to a severely deteriorated rangeland, which likely contributed to a deer population crash in the 1920s. In the early 1920s, Forest Examiner S. B. Locke began investigations to examine the interaction of the large deer herds, livestock grazing, and the degrading range condition. He was joined in 1922 by E. A. Goldman, from the Biological Survey, and in 1924, by new Kaibab National Forest supervisor Walter G. Mann. The Forest Service and Biological Survey worked together to study problems associated with the large deer herd, food supplies, and preferences of deer. They built 41 sample exclosures to protect vegetation from deer browsing. Vegetation within these exclosures was inventoried, photographs taken, and fences maintained from 1925 until at least 1948 under the direction of Mann and Odell 

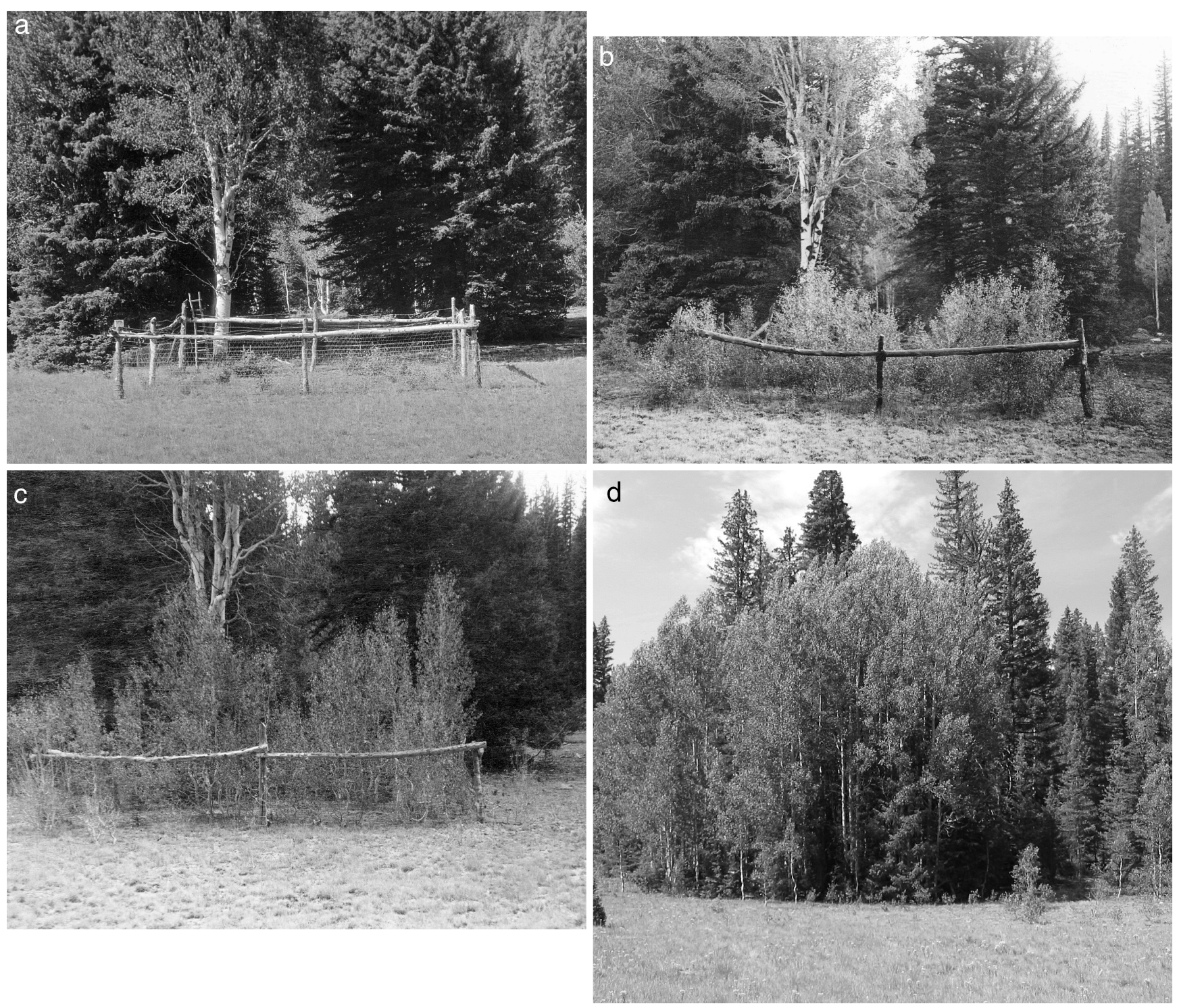

Figure 4. Repeat photographs of Plot \#28 on the Kaibab Plateau as part of the range-aspen-deer studies in $1927 .{ }^{23}$ Each study area had a closed and open plot, and the closed plot or exclosure is shown here in 1930 (top left; photo by E. S. Shipp USFS 253659). On the top right is a 1942 repeat photo by W. G. Mann (USFS 422883). The photo on the lower left shows showing aspen trees exceeding $4 \mathrm{~m}$ by 1948. The lower right photo includes a different field of view ( 50m out in the meadow) to capture the 76 years of aspen height growth (photo by D. Binkley, 2003). The exclosure fence and posts are still evident under the trees. The open plot is located along the forest-meadow border to the right of the closed plot. Historical photos courtesy of Kaibab National Forest, North Kaibab Ranger District, Fredonia, AZ.

Julander (Fig. 4). ${ }^{23}$ During this period, Locke had been in close contact with USFS ranger Aldo Leopold, who visited the Kaibab Plateau in 1941. Leopold wrote a popular account and several scientific articles about the Kaibab deer story. ${ }^{24}$

The Kaibab controversy continued into the 1940s and 1950s when USFS Research range scientists Kenneth W. Parker and Joseph F. Arnold were asked to join the Arizona Game and Fish Department in several studies. A detailed history of the Kaibab deer story and the political, management, and environmental factors that may have played a role in this controversy can be found in several interesting reports. ${ }^{25-27}$

\section{Southwestern Range Research Matures}

A new era in range research began in 1928 with the passage of the McSweeney-McNary Forest Research Act, legislation that specifically authorized experiments in range management. ${ }^{28}$ Expanded funds meant more scientists on more projects. The Fort Valley Experimental Forest Station became the site of USFS Research's headquarters with the new name of USFS Southwestern Forest and Range Experiment Station (SWFRES). This was a temporary arrangement until 1930 when Research moved into rented facilities in Tucson, Arizona. As part of their charge, SWFRES was to coordinate existing range research in District 3, including the Santa Rita and Jornada 
Experimental Ranges. In 1940, the USFS also acquired the Carnegie Institution's Desert Laboratory located on Tumamoc Hill near Tucson when Carnegie closed its operations. ${ }^{29}$ Later, in 1956, the Desert Lab was bought by the University of Arizona. By 1953, the SWFRES was consolidated with the Rocky Mountain Forest and Range Experiment Station and headquartered in Fort Collins, Colorado. In May 1997, the Rocky Mountain Forest and Range Experiment Station and the Intermountain Research Station in Ogden, Utah, merged to become the Rocky Mountain Research Station.

Forester Edward Clayton Crafts began his USFS career in 1932 at SWFRES when he worked on the continuing study of the effect of livestock browsing on the forest. During his seven years in the Southwest, Crafts created a range use survey of all ranger districts in Arizona to describe range conditions and develop guidelines for the proper use of specific ranges. ${ }^{30} \mathrm{He}$ was in charge of the Civilian Conservation Corp (CCC) crews, acting as supervising technician for the camp at Mormon Lake where they worked on tree-thinning. Crafts' career eventually led him to being named as Assistant Chief of the USFS in 1950.

Twenty years of efforts in southwestern rangeland policy implementation resulted in praise as stated in District 3's inhouse publication, Forest Pioneer, of October 1931:

The condition of Arizona ranges is rated 95\% of normal in a special report issued yesterday by the Bureau of Agricultural Economics, USDA. The state's rating stands out by far the best of 17 western states mentioned in the report... Next best in standing are the ranges of New Mexico, rated at $89 \%$ of normal.

A few years later, Region 3's Chief of Range Management D. A. Shoemaker commented in the Forest Pioneer of July 1934:

The Forest Service has been receiving many applications recently from people outside of the forests for grazing privileges on National Forest ranges... The stockmen who are asking admittance to the Forests see feed there which is better than that on many of the outside areas... and it is natural that they should want access to it... But these more favorable conditions on the forests are the result of years of careful management...

Southwestern range studies continued through the 1940s with ongoing research on existing plots and the addition of new plots. Ranger study plots were established in the late 1920s and 1930s, which used permanent livestock exclosures and colocated plots open to grazing to examine range trend, vegetation composition, and cover changes. ${ }^{31}$ Repeat photos showed changes visually. As a result of a study begun about 1950 and involving hundreds of permanent transects around the Southwest, K. W. Parker developed the three-step method for appraising trend in range condition. Step 1 involved data collection on a transect. Step 2 analyzed and classified the data, and Step 3 documented the transect and adjoining area with photographs. Favorable initial reaction to this method was received around the West on both public and private lands, but within a few years, the study was discontinued, primarily because of difficulties in interpreting the data. ${ }^{9,32}$ Parker's method was expanded to five-phase approach in $1973 .{ }^{33}$ Although USFS Districts are not required to remeasure these historical transects, some Districts still use these data as an additional means of examining vegetation change, plant vigor, and erosion.

\section{Experimental Ranges}

\section{Santa Rita Experimental Range}

Bert Potter and colleague Royal S. Kellogg traveled to Tucson in 1901 to meet with Dr David Griffiths of the BPI and Drs R. H. Forbes and J. J. Thornber of the Agricultural Experiment Station at the University of Arizona to explore part of the Santa Rita Forest Reserve that had been recommended as a possible site for an experimental range. Located south of Tucson, the Santa Rita was officially set aside in 1903 as the nation's first Range Reserve. It was managed by the BPI until 1915, when the USFS took it over. Its desert grasslands contain more than 51,000 federally owned acres and some 1,300 privately owned acres. Because of severe overgrazing since the 1880s, livestock were excluded from much of the Santa Rita until 1915 when the USFS reinstated year-long grazing with cooperators. In 1989, the USFS transferred management of Santa Rita to the University of Arizona which continues studies on this century-old reserve. ${ }^{34}$ Literally hundreds of studies have taken place on the Santa Rita to examine different livestock grazing systems, vegetation control and restoration practices, and impacts of small mammals and other consumers. ${ }^{35}$

\section{Jornada Experimental Range}

Another major, long-term Experimental Range in the Southwest is the Jornada, located in the Chihuahuan Desert northeast of Las Cruces, New Mexico. In 1904, E. O. Wooton, a visionary botanist with the New Mexico College of Agriculture and Mechanic Arts, began a series of studies in cooperation with $\mathrm{C}$. T. Turney, a rancher who was grazing the Jornada after gaining control of the local water sources. More than 190,000 acres were set aside in 1912 by Presidential Executive Order, thus forming the Jornada Range Reserve. In 1915, management of the Jornada transferred from the BPI to the USFS, and W. R. Chapline established the valuable Jornada Herbarium. The Jornada Range Reserve was renamed the Jornada Experimental Range in 1927. Then in 1954, Jornada management was transferred to the Agricultural Research Service, which manages the facility today along with New Mexico State University. The Jornada Experimental Range is also designated as a Long Term Ecological Research (LTER) site. ${ }^{36}$ 


\section{Conclusions}

USFS Range Research was born in the Southwest because of people like Bert Potter and Will C. Barnes, stockmen who worked to ensure rangeland and ranching sustainability. Initial efforts between bureaucrats and ranchers were harmonious, but tensions soon began and are still with us today. Research, however, has proceeded carefully through the turmoil.

Range scientists first came into the Southwest with the nation's initial range reconnaissance survey. Southwestern Forest Service scientists not already mentioned from the 1910s to the 1970s include Earl Aldon, Jack Bohning, Dwight Cables, Robert S. Campbell, R. H. Canfield, J. T. Cassady, Warren Clary, Pete Ffolliott, C. L. Forsling, G. E. Glendening, B. A. Hendricks, Donald A. Jameson, E. L. Little, Jr., S. Clark Martin, W. G. McGinnies, G. D. Merrick, Enoch W. Nelson, H. A. Paulson, Jr., Henry A. Pearson, F. W. Pond, Elbert H. Reid, and H. G. Reynolds, among others.

USFS range research, per se, ended about 1970, and scientific projects relating to rangeland use began to be funded under the umbrella of watershed, wildlife, and ecological projects with a shift from agricultural (increased forage) to conservation as public image about forest and range use changed. Today's USFS scientists collaboratively work with other agencies and organizations continuing studies under several venues, for example, Northern Arizona University's Ecological Restoration Institute, the Malpai Borderlands Group in southeastern Arizona, Sevilleta long-term ecological research (LTER) site in central New Mexico, and traditional range and watershed departments at New Mexico State University and University of Arizona. Academicians at Arizona State University also undertake teaching and research in rangeland science.

Changing climatic conditions, markets, cultural traditions, and other reasons factor into public lands grazing. Sound research combined with multiple methods must be employed to ensure the best sustainable use of the natural resources in any given area with close attention paid to the extremely diverse climate and topography of the Southwest. It is a complex issue and everyone has his or her own opinion. Edward Crafts said a final determination on whether livestock did harm to pine tree reproduction was never determined one way or the other. ${ }^{30}$ Discerning, once and for all, how to manage the range is impossible because so many components affect any given forest and range area, and decisions must be based on the resources of the individual area at that time in its history. Controversy will continue, as will rangeland research, because at any given moment, the value of land ebbs and flows with cultural perception.

For a more comprehensive review of range research throughout the western United States, the reader is referred to the Journal of Range Management. . $^{37,38}$

\section{Acknowledgments}

The authors are grateful to Dennis Lund for locating the historic Kaibab photos. Special thanks to Rocky Mountain
Research Station Project Leader Carl Edminster for his support. And, thanks to all of the visionary ranchers, range scientists, and range managers who cared about the rangeland resources of the Southwest.

Authors are Archivist and Historian, USDA Forest Service Rocky Mountain Research Station, Fort Valley Experimental Forest Station, Flagstaff, AZ (Olberding); Rangeland Scientist, USDA Forest Service Rocky Mountain Research Station, Fort Collins, CO (Mitchell); and Professor, School of Forestry, Northern Arizona University, Flagstaff, AZ (Moore).

\section{References and Other Reading}

1. Tucker, E. A., And G. FitzPatrick. 1972. Men who matched the mountains. USDA Forest Service, Southwestern Region.

2. United States Department of Commerce (USDC). 1943. Sixteenth census of the United States, 1940. Agriculture (Gen. Rep.) 3:9-1092.

3. Miller, F. H. 1921. Reclamation of grass lands by Utah juniper on the Tusayan National Forest, Arizona. Journal of Forestry 19:6.

4. Holechek, J. L., R. D. Pieper, And C. H. Herbel. 2004. Range management: Principles and practices. 5th edition. Upper Saddle River, NJ: Pearson and Prentice Hall Press, Inc.

5. Toumey, J. W. 1891. Overstocking the range. Tucson, AZ: Agricultural Experiment Station, University of Arizona. Bulletin 2.

6. Wooton, E. O. 1908. The range problem in New Mexico. Las Cruces, NM: New Mexico College of Agriculture and Mechanic Arts. Agriculture Experiment Station. Bulletin 66.

7. Pinchot, G. 1947. Breaking new ground. New York, NY: Harcourt Brace Jovanovich, Inc.

8. Jardine, J. T., AND M. Anderson. 1919. Range management on the national forests. Washington, DC: USDA. Bulletin 790.

9. Rowley, W. D. 1985. U.S. Forest Service grazing and rangelands: a history. College Station, TX: Texas A\&M Press.

10. Thornber, J. J. 1910. Grazing ranges of Arizona. Tucson, AZ: Arizona Agriculture Experiment Station. Bulletin 65. p 245-360.

11. HiLL, R. R. 1917. Effects of grazing upon western yellow pine reproduction in the national forests of Arizona and New Mexico. Washington, DC: US Department of Agriculture. Bulletin 580.

12. Pearson, G. A. 1923. Natural reproduction of western yellow pine in the Southwest. Washington, DC: USDA Forest Service. Bulletin No. 105.

13. Pearson, G. A. 1933. A twenty-year record of changes in an Arizona pine forest. Ecology 4:272-285.

14. Talbot, M. W., And R. R. Hill. 1923. Progress report on the range study plots on the Coconino National Forest comprising a description of project and digest of data. Unpublished report on file at Fort Valley Experimental Archives, Flagstaff, AZ.

15. ARnold, J. F. 1950. Changes in ponderosa pine bunchgrass ranges in northern Arizona resulting from pine regeneration and grazing. Journal of Forestry 48:118-126. 
16. Glendening, G. E. 1941. Work plan-summer 1941: Hill study plots, Coconino. Flagstaff, AZ: Fort Valley Experimental Forest Station Archives.

17. BAKKER, J. D. 2005. Long-term understory dynamics of ponderosa pine forests [PhD dissertation]. Flagstaff, AZ: Northern Arizona University. 175 p.

18. Pearson, G. A. 1910. Reproduction of western yellow pine in the Southwest. Washington, DC: USFS. Circular 174.

19. Diary found in Fort Valley Experimental Forest Station Archives, USFS Rocky Mountain Research Station, Flagstaf, Arizona.

20. Pearson, G. A. 1950. Management of ponderosa pine in the Southwest as developed by research and experimental practice. Washington, DC: USDA Forest Service. Agricultural Monograph No. 6.

21. Talbot, M. W., And F. P. Cronemiller. 1961. Some of the beginnings of range management. Journal of Range Management 14:95-102.

22. Chapline, W. R. 1919. Production of goats on far western ranges. Washington, DC: US Department of Agriculture.

23. ManN, W. G. 1941. The Kaibab deer: A brief history and present plan of management. Williams, AZ: USDA Forest Service, Kaibab National Forest (original 1931 report amended 1934 and 1941).

24. LeOpold, A. 1943. Deer irruptions. Wisconsin Conservation Bulletin 8:3-11.

25. Mitchell, J. E., And D. R. Freemann. 1993. Wildlife-livestock-fire interactions on the North Kaibab: A historical overview. Fort Collins, CO: USDA Forest Service Rocky Mountain Research Station. General Technical Report RM-222.

26. Binkley, D., M. M. Moore, W. H. Romme, And P. M. BROWN. 2005. Was Aldo Leopold right about the Kaibab deer herd? Ecosystems (in press).

27. YounG, C. C. 2002. In the absence of predators: conservation and controversy on the Kaibab Plateau. Lincoln: University of Nebraska Press.
28. Chapline, W. R., R. S. Campbell, R. Price, and G. STEWART. 1944. The history of western range research. Agricultural History 18:127-143.

29. Olberding, S. D. 2000. Fort Valley: the beginnings of forest research. Forest History Today. Spring 2000.

30. Crafts, E. C., and S. R. Schrepfer. 1972. Edward C. Crafts: forest service researcher and Congressional liaison-An eye to multiple use. Forest History Society.

31. Turner, R. M., L. H. Applegate, P. M. Bergthold, S. GALLIZIOLI, AND S. C. MARTIN. 1980. Arizona range reference areas. Ogden, UT: USDA Forest Service Rocky Mountain Research Station. General Technical Report RM-79.

32. Brady, W. W., J. W. Cook, And E. F. Aldon. 1991. A microplot method for updating loop frequency range trend data: theoretical considerations and a computer simulation. Fort Collins, CO: USDA Forest Service Rocky Mountain Research Station. Research Paper RM-295.

33. Reppert, J. N., AND R. E. FranCIS. 1973. Interpretation of trend in range condition for 3-step data. Fort Collins, CO: USDA Forest Service. Research Paper RM-103.

34. University of ArizonA, College of Agriculture. 2004. Santa Rita Experimental Range home page. Available at: http://ag.arizona.edu/SRER.

35. McClaran, M. P., P. F. FFolliott, and C. B. Edminister [TECH. COORD.]. 2003. Santa Rita Experimental Range: 100 years (1903 to 2003) of accomplishments and contributions. Ogden, UT: USDA Forest Service Rocky Mountain Research Station. P-30.

36. USDA, Agricultural Research Station, Jornada Experimental RAnge. 2005. Jornada Research. Available at: http://usda-ars.nmsu.edu.

37. YounG, J. A. 2000. Range research in the far western United States: the first generation. Journal of Range Management 53:2-11.

38. Young, J. A., AND C. D. Clements. 2001. Range research: The second generation. Journal of Range Management 54:115-121. 